Article

\title{
Unraveling the (Uneven) Linkage? A Reflection on Population Aging and Suburbanization in a Mediterranean Perspective
}

\author{
Sirio Cividino ${ }^{1}$, Gianluca Egidi ${ }^{2}$ and Luca Salvati ${ }^{3, *}$ \\ 1 Department of Agriculture, University of Udine, Via del Cotonificio 114, I-33100 Udine, Italy; \\ sirio.cividino@uniud.it \\ 2 Department of Agricultural and Forestry Sciences (DAFNE), Tuscia University, Via S. Camillo de Lellis, \\ I-01100 Viterbo, Italy; egidi.gianluca@unitus.it \\ 3 Department of Economics and Law, University of Macerata, Via Armaroli 43, I-62100 Macerata, Italy \\ * Correspondence: luca.salvati@unimc.it; Tel.: +39-0657-1036
}

Received: 22 April 2020; Accepted: 30 May 2020; Published: 3 June 2020

\begin{abstract}
A complex interplay between socioeconomic transformations and demographic dynamics has characterized the long-term development of European countries. As a characteristic example of such linkage, the present study focuses on the spatial relationship between metropolitan growth and population age structure. Preferences for urban and suburban locations reflect complex socioeconomic phenomena such as sprawl, class segregation, gentrification and filtering. However, the spatial linkage between sprawl and demographic transitions was relatively poorly analyzed, and should be more extensively investigated in relation with population dynamics and socioeconomic structures at local scale. By reviewing pertinent literature, this study outlines how space exerts a non-neutral impact on population age structures in Europe, shaping housing needs and influencing settlement patterns and processes of urban transformation. While suburban locations have concentrated younger families and larger households in Northern and Western Europe, the socio-demographic composition of new settlements is increasingly dominated by older inhabitants in the Mediterranean region. Results of this work suggest how discontinuous urban expansion was specifically associated with an elder, wealthy population with high standard of living and a preference for specific housing locations such as detached villas with gardens and swimming pools.
\end{abstract}

Keywords: demographic transition; age structure; suburban areas; Mediterranean Europe

\section{Introduction}

A complex interplay between socioeconomic alterations and the underlying demographic trends has characterized the long-term development path of Europe, especially in recent decades [1-4]. Demographic transitions are considered a sign of "a pathway to change" typical of the contemporary societies and economies [5-7]. The first demographic transition resulted in decreasing birth and death rates from traditionally high levels typical of a pre-transitional, stable population state [8-10]. The end of this transition in Europe was reflected in population concentration in urban areas between the 1960s and the 1970s [11-13]. The subsequent demographic change (hereafter called the 'second demographic transition') was characterized by important social transformations and more latent processes of demographic redistribution across regions [14], triggering a greater heterogeneity in population dynamics, time of childbearing, households' size, individual choices concerning marriage or cohabitation, and aging [15].

While the first demographic transition has reflected intense socioeconomic change along urban-rural gradients [16], impacts of the second demographic transition were more evident when 
comparing population dynamics in urban and suburban locations [17]. In these regards, a completely new spatial structure of population and settlements has progressively been established in Europe, replacing the traditional divide in urban and rural areas with a more subtle configuration opposing suburban locations to both central cities and rural districts [18]. Following these transitions, specific processes of family formation such as marriage or cohabitation were particularly variable over space during the second demographic transition [19-21], with less polarized gender roles [22-24]. At the same time, demographic dynamics resulted that were more sensitive to economic shocks [25-27], reflecting intense and non-linear relationships between socio-demographic change and short-term economic downturns $[28,29]$.

The present study focuses on the relationship between urban growth and population age structure as a result of locally differentiated demographic transitions characteristic of long-term development processes in Europe. Taken as an example of the complex interplay between socioeconomic transformations and demographic dynamics, preferences for urban and suburban locations reflect socioeconomic phenomena such as sprawl, gentrification, class segregation, and filtering. Assuming space as a non-neutral factor impacting population age structures, shaping housing needs and influencing settlement patterns and processes of socioeconomic transformations in metropolitan regions, we reviewed pertinent literature to demonstrate that the spatial linkage between sprawl and demographic transitions was relatively poorly analyzed in Mediterranean Europe. A refined understanding of such dynamics requires an extensive investigation of spatially varying population trends and socioeconomic contexts (Figure 1).
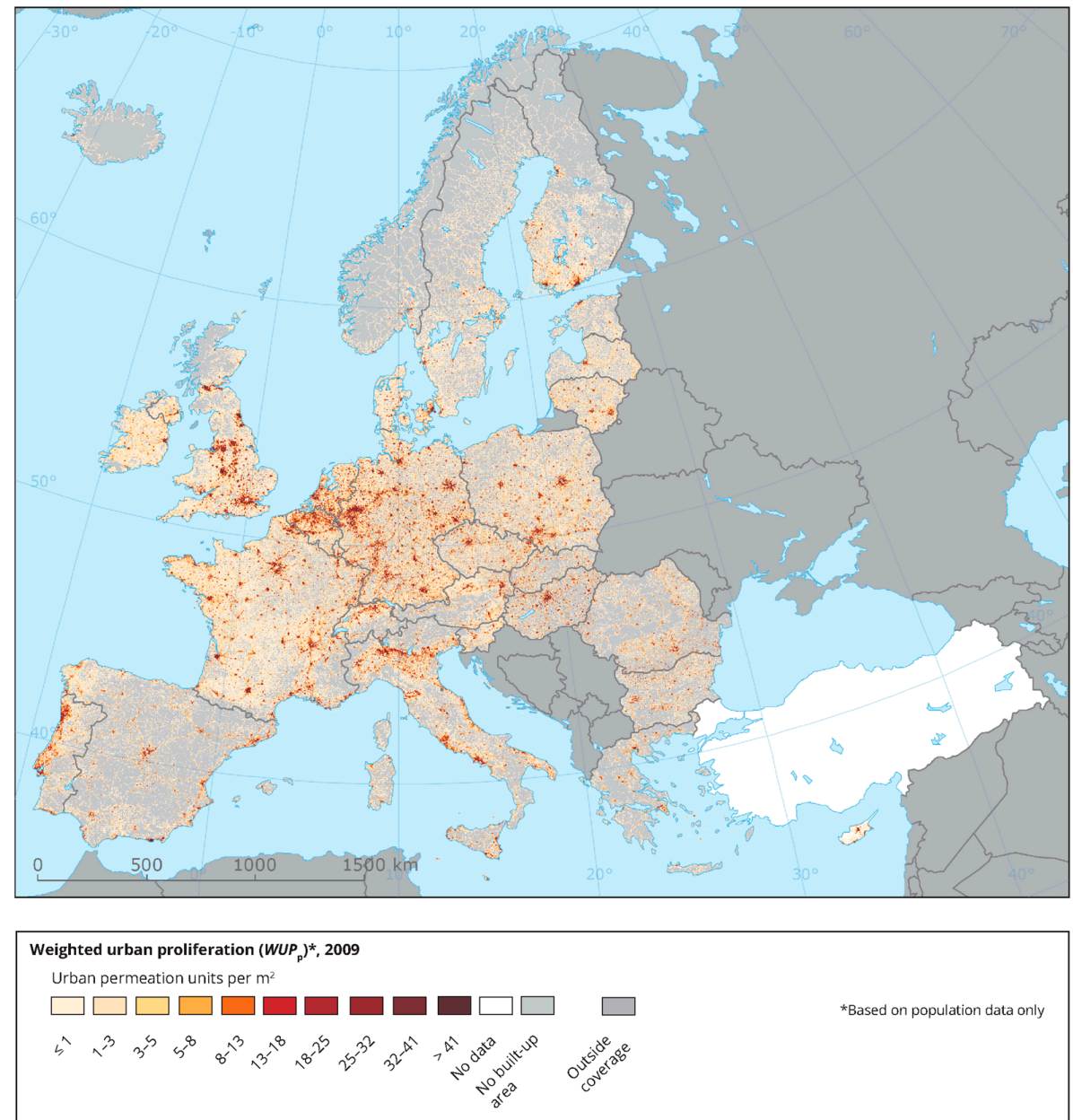

Figure 1. Urban expansion in Europe based on a composite index of settlement proliferation (Source: European Environment Agency). 
While younger families and larger households dominated the socioeconomic profile of suburban locations, new settlement types-especially discontinuous urban fabric-were frequently dominated by older households in Mediterranean countries. More specifically, urban sprawl in Southern Europe was increasingly associated with an elder, wealthy population with high standard of living and a preference for housing segments such as detached villas with private gardens and swimming pools. Since different population segments by age may have distinctive housing needs, an in-depth analysis of preferences for urban or suburban locations is key to understanding latent relationships between settlement patterns and demographic transitions [30,31]. To answer this deserving research issue, the present work provides a review of spatial settlement preferences of young and older households, outlining the specificity of Mediterranean socio-demographic settings with respect to other countries in both Western, Northern and Eastern Europe.

\section{Spatial Preferences of Young}

Age is a key factor of individual's residential preferences [32-34]. Housing types are assumed to reflect distinctive residential preferences of specific age groups in Europe [35]. Age structure, household size, density of unoccupied houses, and population concentration were demonstrated to differently characterize discontinuous settlements during demographic transitions in Southern Europe [36]. The most recent socioeconomic transitions were associated with a progressive shift from compact cities to polycentric (and spatially balanced) urban settlements [37]. Under stable (or slightly negative) natural population balance (births minus deaths), internal and international migration represent the engine of demographic changes [38-41]. Internal migration was a traditional process shaping urban-rural divides in Mediterranean countries for decades; working-age international migration fuelled urban growth especially in the last two to three decades [42-44]. Immigration from Eastern Europe and non-European developing countries have been particularly strong in highly segregated labor markets up to the late 2000s [45]. Young migrants were particularly incline to settle in core cities, being predominant in low-quality, central neighborhoods [46-48] offering job opportunities, better public transport, cheaper housing, and networking [49-51].

Age shapes population mobility since younger households endorse sprawl by demanding less busy neighborhoods in quiet and reasonable locations [52], escaping from urban lifestyles typical of modern societies [53]. Young couples with children were particularly demonstrated to establish preferentially in residential rural settlements with green areas [54] because (i) housing prices are usually lower than in strictly urban areas and (ii) suburban settlements can fulfill a specific demand for bigger dwellings that are unaffordable in central cities [55-58]. Housing preferences of young families in suburban Europe have been investigated since the 1970s, when a large number of people chose to live in large apartments or in detached or semi-detached houses, because of the appropriateness of suburbs for larger households with children [59]. In Mediterranean Europe, however, suburbanization was also associated with additional factors such as proximity to the sea coast and settlement informality [60-63]. For instance, sprawl in Barcelona was defined as a sort of 'lock living' housing model, leading to landscapes more similar to the United States suburban archetype than to Northern and Western Europe dispersed settlements [64-66].

Suburban landscapes in Mediterranean areas are usually constituted of detached houses with gardens and swimming pools, revealing an intrinsic relationship between pool density and household wealth at the local scale [67-70]. The socio-demographic profile of suburban settlements was dominated for a long time by households typically composed of young couples with children. By contrast, one-component households (e.g., foreign migrants and native older people, young singles, or divorced adults who live alone) showed a preference to live in urban locations, because of higher accessibility to public services [71]. However, immigration from developing countries fueled an intense spatial redistribution of population from compact cities to suburban districts [72]. In countries such as Italy and Spain, the most significant factors driving spatial mobility were (i) the increasing population pressure in compact cities as a result of the "baby boom" of the 1970s, (ii) rising house prices in 
the 1980s, as well as (iii) land availability constraints and a growing demand for more living space coupled with increasing household income in the 1990s [73,74]. For instance, compact residential urban settlements in Catalonia rose from 379 to $409 \mathrm{~km}^{2}$ between 1987 and 2002, growing by 7.9\% (European Environment Agency, 2006). By contrast, low-density urban land area increased from 271 to $581 \mathrm{~km}^{2}$, rising by $114 \%$ in the same time period [75]. In Spain, low-density settlements were demonstrated to reflect cultural changes, socio-demographic transformations and a generalized growth of disposable income for households [76].

Socioeconomic variables such as income or citizenship also have a greater weight on car ownership. Assuming that education level is associated with job employment and working location [23], high incomes account for a greater use of car, whereas private mobility decreases for workers with lower education levels and foreigners. Car ownership in families residing in high-density settlements is much lower than in families settling the new dispersed suburbs [77]. A high number of graduates with jobs settling in central cities results in a lower use of private transport [78]. In traditional compact cities, journeys are shorter and car use is relatively low [79], with higher densities and land-use mix enabling residents to perform more activities in a single journey. By reducing the total number of trips by $20 \%$, compact settlements facilitate foot or bicycle mobility and the provision of public transport [80].

While young people who want to create a family prefer suburban locations, younger people-students, early workers—demand urban locations (Christie et al., 2017; Tucker-Raymond and Rosario, 2017), being mostly flat sharers [81-85]. This phenomenon has been more recently observed in Southern Europe than in Western and Northern Europe, occurring primarily in 'university' cities [86]. At the same time, one-person households and cohabiting couples below 35-40 years also play a role in re-urbanization dynamics [30]. Re-urbanization is a comparatively recent phenomenon in Southern Europe [31], consolidating residential functions in central cities [87]. Re-urbanizing Mediterranean cities, however, was demonstrated only in few cases, since urbanization stimuli still coexist and interconnect largely with other socio-demographic processes including settlement sprawl, class segregation, gentrification, and filtering [88].

Empirical results of earlier studies suggest that the impact of age on residential dynamics basically dealt with life course, household size, urban cycle, and economic downturns [49]. Young adults' choices to live in inner cities (or outer suburban areas) depend on household composition and social status [89]. Furthermore, the increasing diversity of lifestyles and household types suggests that age could be less significant in defining residential location in the coming future [90]. Conversely, the rising segregation of age groups in education, and the division of labor and consumption practices, outline a rising importance of age in defining residential contexts [91-93].

\section{Spatial Preferences of Elders}

Europe faced a huge expansion of residential settlements in urban areas $[42,53,63,94-96]$. The Mediterranean region has experienced continuous urbanization occurring especially along the coastline and in internal lowland [97-100]. In flat areas, sprawl was particularly evident in the last decades, because of the uneven expansion of urban networks fueled by service-oriented economies and tourism [101-103]. Together with economic growth and tourism, one of the driving forces was international retirement migration, a recent process reflecting the increasing residential movements of retired people from different parts of the world [104]. Different explanations for the rapid increase of international retirement migration, for example, from Northern to Southern Europe or from Canada/United States to selected Caribbean islands or Florida, were increasingly studied [105]. International retirement migration embraces an aging population, delay of active old age, improved but differentiated disposable income, varying retirement patterns, and enlarged familiarity with 'global' working and vacation patterns [106].

Older adults are less likely to influence their residential environment, as they tend to travel outside their own neighborhoods less often than younger adults do [107-109]. However, retirees embody one of the current kinds of population that change their place of residence more frequently than in the past, 
seeking for a better life quality [110]. Earlier studies investigated the motivations underlying the choice of older people to move abroad after retirement, considering together consolidated lifestyles and social networks [111]. Retirement migration reflects a kind of residential migration, which happens because of an increased demand for 'self-fulfillment' or the 'good life' [112]. North-South retirement migration within Europe can be related back to the 1992 Maastricht Treaty [113-115], allowing free movement of European citizens within the continent and giving them the chance to export rights to healthcare and other social security schemes [116]. As a result of European integration, retirees settled preferentially in coastal districts all over the Northern Mediterranean basin, from Portugal to Greece [117]. Four types of older-age migrants were identified in Europe: (i) those who had gone from being a tourist to being resident, whose major explanation for emigrating was the enhancement of life quality owing to, for example, agreeable climatic conditions and lower cost of living [118]; (ii) those who both worked and retired in the destination country [119]; (iii) people retired in their country of origin and regrouped with their children [120]; and (iv) those who immigrated to Southern countries to reside in a dwelling for old people, since it is cheaper than in (origin) countries [121].

The concept of 'international retirement migrants refers to Northern European retirees who decide to reside (seasonally or permanently) in Southern Europe, counting both those who have migrated previously and subsequently their retirement [111]. They are also called "residential tourists" or "lifestyle movers" [122]. Today, Italy, Portugal, and Spain are the preferred countries by people in retirement age (or close to it) from Northern and Central European countries [105,123,124]. These migrants usually display a strong demand for rural lifestyle or a seasonal escape from contemporary life [125]. Residential mobility has rapidly grown since the 1980s because of globalization and background socio-political factors [126,127]. By attracting a substantial flow of residential mobility from Northern countries, Mediterranean regions still remain the most suitable places for retirement migrants in Europe because of climatic conditions and lower costs of living [128-130]. For instance, an increasing number of retired migrants from Great Britain decided to migrate to Southern Europe [125]. There has been a long tradition of United Kingdom natives residing in Spain since the 1950s, with a boom in the 1980s; this generation is now ageing. It is estimated that $40 \%$ of UK nationals living in Spain are over 50 years of age, and that a large percentage have been living there for decades [98]. These migrants were attracted to Spain thanks to the combination of a high quality of life, warm and sunny climate, and low housing costs-although this has changed to some degree with housing price inflation and, more recently, with a change in the exchange rate devaluing the Pound against the Euro [131].

International retirement migration reflects social consequences that have been underexplored up to now [132-134]. This lack of knowledge conflicts with the economic influence this population segment exerts both in their countries of origin and settlement. However, migration studies based on older people have been exclusively focused on wealthy Northern Europeans moving to the sunniest Mediterranean coasts [135]. In the last decades, earlier studies explored social, demographic, and economic consequences of retirement migration, giving only limited attention to negative environmental externalities and indirect impacts on landscapes [136-138]. In this regard, it was demonstrated how international retirement migration fueled an increased demand for new residential areas close to natural amenities $[97,126,139]$. Local and foreign people settled in smaller land plots fueled residential development along the sea coasts [140-142], leading to mixed housing typologies and a substantial increase of foreign residential tourists, as observed in Southern Spain with retired British people $[112,143,144]$. In these regards, some of the largest and most important districts receiving people in retirement age (or close to it) from other countries were located in Spain [99]. In Alicante, an intense real estate bubble in the late 2000s and the continuous arrival of European foreigners altered the urban outline since most development took place on low-priced land in the less-developed provincial areas, while the already urbanized Northern (and richer) areas expanded moderately [145].

Concerning income levels, most retirees worked as skill employees $(60 \%)$ or as self-employed business owners (25\%) before retiring, and $65 \%$ had a net month income higher than $€ 1500$. Among 
European retirees, many of them chose to buy their second house in suburban areas. There are different forms of migration at both the international and domestic scale with regard to the second house, arising from tourism and migration processes [146]. Lifestyle choice can exert a significant influence on residential relocation behaviors, particularly at specific stages in the household or individual life-cycles [147-149]. Migration to rural areas or peri-urban neighborhoods was related to an intrinsic demand to satisfy lifestyle choices associated to leisure values [150-152]. The home situation plays a major role in aging, with older people having a familiar and safe location in which to follow their activities [153].

Second homes contribute to maintain a more familiar environment giving the best opportunity for relaxation and improving the perception of a 'residential idyll'. The desirability of second-home living should be measured within the background of the destination image, assuming that countryside offers a good quality of life. For instance, most second homes in the Alicante region comprised multiple options for activities (e.g., cycling, walking, and golf) [126]. Such patterns have significant implications for the existing farms, since land prices may rise in response to accelerated demand from 'lifestyles' migrating from urban centers and/or non-permanent second homeowners [154]. These processes can be regarded as a sort of rural gentrification leading to fragmented land ownership, increasing human impact and greater disturbance of local ecosystems [155]. In such contexts, native population and migrants (with temporary or permanent second homes) may occupy a 'shared but separate' geographic space with considerable consequences for resilience of local communities, counting environmental and political issues, and long-term sustainability [156-158].

\section{Concluding Remarks}

This commentary reviews housing preferences of population by age group in Mediterranean Europe. Earlier studies indicate how urban sprawl depends mainly on young people with greater propensity to marriage and childbearing. Younger people prefer strictly urban contexts [159-161]. Elders tend to live in consolidated settlements in both central cities and peripheral neighborhoods [131, $162,163]$. In recent decades, suburbs have become a preferred location for two population segments: (i) young people, who usually move to these locations demanding houses with a garden, and (ii) retired people, choosing these contexts for quietness and mild climate [116]. In fact, retired people preferentially choose the coastal districts of Mediterranean Europe to spend their free time seasonally or permanently. Spain and Portugal are the most coveted contexts, as described in the literature [125]. Generally speaking, rural areas concentrate older residents, because of locally-specific trends in urbanization and re-urbanization [164]. At the same time, the relationship between population age structure and place is not as simple as the rural-urban distinction; for instance, a substantial difference in the age structure of rural population was observed across European regions [73,93,118].

Residential mobility and relocation in quiet, often tourism-related areas with an agreeable climate for the elderly is a recent but problematic phenomenon. Since the 1980s, regional development and wealth redistribution in most European countries have improved the disposable income for vacation purposes [106]. Such welfare added to the growing internationalization of mass tourism, shaping labor migration [156]. Furthermore, the spread of both arrangements of pension schemes (e.g., state, occupational, and personal) and capital accumulation through the property market (usually house ownership or inherited property) has improved prosperity and income availability at the retirement stage of the life course, enabling different types of tourism-related migration [165-167]. While considering a wealth of pertinent literature, this study acknowledges the intrinsic limitations of this type of bibliographic analysis that depends on subjective selection of earlier studies. Future research is increasingly required to focus on population aging and sustainable development, linking retirement migration, social vulnerability of the elderly, the decline of suburbs, and distinctive cultural/socio-demographic changes in urban and suburban areas [168].

Since demographic transitions have traditionally paralleled urban dispersion trends [167], the young families of the 1980s, originally settling in low-density contexts in larger houses and having 
childbearing prospects, are now getting older and restrained in still dispersed settlements where it is essential to use a car to reach services or activities [131]. Such outcomes are rapidly shaping the socioeconomic composition of Mediterranean suburbs, making them progressively more similar to the traditional United States suburbs. While suburbs have been considered as the American 'idyll', having younger families and larger households at the base of the United States dream [169], current population living in such areas is aging [5]. Restricted mobility, especially where substitute transportation options are less available or unreachable [165], is just one of the problems affecting elders in contemporary suburbs. A greater consideration of the multifaceted implications of suburban population aging in Mediterranean areas forms the appropriate background to design strategies enforcing sustainability and resilience of local communities. In addition to transportation, lack of public service infrastructures is a particularly important issue creating insurmountable problems to older inhabitants [170]. Among others, referring to the gerontological literature on 'aging in place' would provide a useful perspective informing a truly sustainable spatial planning oriented toward the specific demands of a progressively older population [168]. Identifying additional issues posing challenges for spatial planning of getting-older settlements is an urgent need for European-and especially Mediterranean-social scientists interested in socioeconomic and environmental dynamics characteristic of peri-urban communities.

Author Contributions: Conceptualization, G.E. and S.C.; methodology, L.S.; validation, G.E.; investigation, S.C.; resources, S.C.; writing—original draft preparation, L.S.; writing—review and editing, S.C.; visualization, G.E.; supervision, G.E.; project administration, G.E.; funding acquisition, G.E. All authors have read and agreed to the published version of the manuscript.

Funding: This research received no external funding.

Conflicts of Interest: The authors declare no conflict of interest.

\section{References}

1. Haase, A.; Kabisch, S.; Steinführer, A.; Bouzarovski, S.; Hall, R.; Ogden, P.; Steinführer, A. Emergent spaces of reurbanisation: Exploring the demographic dimension of inner-city residential change in a European setting. Popul. Space Place 2009, 16, 443-463. [CrossRef]

2. Lesthaeghe, R. The Unfolding Story of the Second Demographic Transition. Popul. Dev. Rev. 2010, 36, 211-251. [CrossRef] [PubMed]

3. Van Nimwegen, N. Population change in Europe: Turning challenges into opportunities. Genus 2013, 69, 103-125.

4. Salvati, L. The Dark Side of the Crisis: Disparities in per Capita income (2000-2012) and the Urban-Rural Gradient in Greece. Tijdschrift voor Economische en Sociale Geografie 2016, 107, 628-641. [CrossRef]

5. Lee, R.D.; Reher, D.S. Introduction: The Landscape of Demographic Transition and Its Aftermath. Popul. Dev. Rev. 2011, 37, 1-7. [CrossRef]

6. Reher, D.S. Economic and Social Implications of the Demographic Transition. Popul. Dev. Rev. 2011, 37, 11-33. [CrossRef]

7. Van Criekingen, M. 'Gentrifying the re-urbanisation debate', not vice versa: The uneven socio-spatial implications of changing transitions to adulthood in Brussels. Popul. Space Place 2009, 16, 381-394. [CrossRef]

8. Surkyn, J.; Lesthaeghe, R. Value Orientations and the Second Demographic Transition (SDT) in Northern, Western and Southern Europe: An Update. Demogr. Res. 2004, 3, 45-86. [CrossRef]

9. Coleman, D. Europe's Demographic Future: Determinants, Dimensions, and Challenges. Popul. Dev. Rev. 2006, 32, 52-95. [CrossRef]

10. Cherlin, A. Demographic Trends in the United States: A Review of Research in the 2000s. J. Marriage Fam. 2010, 72, 403-419. [CrossRef]

11. Salvati, L.; Carlucci, M. Urban growth, population, and recession: Unveiling multiple spatial patterns of demographic indicators in a Mediterranean City. Popul. Space Place 2017, 23, e2079. [CrossRef]

12. Salvati, L.; Sateriano, A.; Grigoriadis, E. Crisis and the city: Profiling urban growth under economic expansion and stagnation. Lett. Spat. Resour. Sci. 2015, 9, 329-342. [CrossRef] 
13. Salvati, L.; Sateriano, A.; Grigoriadis, E.; Carlucci, M. New wine in old bottles: The (changing) socioeconomic attributes of sprawl during building boom and stagnation. Ecol. Econ. 2017, 131, 361-372. [CrossRef]

14. Lesthaeghe, R.J.; Neidert, L.J. The Second Demographic Transition in the United States: Exception or Textbook Example? Popul. Dev. Rev. 2006, 32, 669-698. [CrossRef]

15. Kreyenfeld, M.; Andersson, G.; Pailhé, A. Economic Uncertainty and Family Dynamics in Europe: Introduction. Demogr. Res. 2012, 27, 835-852. [CrossRef]

16. Salvati, L.; Zambon, I.; Chelli, F.M.; Serra, P. Do spatial patterns of urbanization and land consumption reflect different socioeconomic contexts in Europe? Sci. Total. Environ. 2018, 625, 722-730. [CrossRef] [PubMed]

17. Cecchini, M.; Cividino, S.; Turco, R.; Salvati, L. Population Age Structure, Complex Socio-Demographic Systems and Resilience Potential: A Spatio-Temporal, Evenness-Based Approach. Sustainability 2019, 11, 2050. [CrossRef]

18. Kalmijn, M.; Van Tubergen, F. Ethnic intermarriage in the Netherlands: Confirmations and refutations of accepted insights. Eur. J. Popul. 2006, 22, 371-397. [CrossRef]

19. Killewald, A. Money, Work, and Marital Stability. Am. Sociol. Rev. 2016, 81, 696-719. [CrossRef]

20. Mikolai, J.; Kulu, H. Divorce, Separation, and Housing Changes: A Multiprocess Analysis of Longitudinal Data from England and Wales. Demography 2018, 55, 83-106. [CrossRef]

21. Lamidi, E.O.; Manning, W.D.; Brown, S.L. Change in the Stability of First Premarital Cohabitation among Women in the United States, 1983-2013. Demography 2019, 56, 427-450. [CrossRef] [PubMed]

22. Vikat, A. Women's labor force attachment and childbearing in Finland. Demogr. Res. Spec. Collect. 2004, 8, 177-212. [CrossRef]

23. Hoem, J.M.; Neyer, G.; Andersson, G. Education and childlessness: The relationship between educational field, educational level, and childlessness among Swedish women born in 1955-1959. Demogr. Res. 2006, 14, 331-380. [CrossRef]

24. Ohlsson-Wijk, S.; Turunen, J.; Andersson, G. Family Forerunners? An Overview of Family Demographic Change in Sweden. Stockh. Res. Rep. Demogr. 2017, 13, 65-77.

25. Lee, K.O.; Painter, G. What happens to household formation in a recession? J. Urban Econ. 2013, 76, 93-109. [CrossRef]

26. Lee, J.; Hong, S.; Park, Y. Predictable Surprise: The Spatial and Social Morphology of Aging Suburbs in the US Metropolitan Areas. Sustainability 2017, 9, 458. [CrossRef]

27. Rontos, K. Demographic trends, young people's attitudes towards marriage and socio-economic changes related to family formation in Greece and in selected European Countries: A comparative analysis based on official and survey research data. Int. J. Criminol. Sociol. Theory 2010, 3, 543-562.

28. Musick, K.; Michelmore, K. Change in the Stability of Marital and Cohabiting Unions Following the Birth of a Child. Demography 2015, 52, 1463-1485. [CrossRef]

29. Wu, Z.; Penning, M. Marital and Cohabiting Union Dissolution in Middle and Later Life. Res. Aging 2017, 40, 340-364. [CrossRef]

30. Moos, M. "Generationed" space: Societal restructuring and young adults' changing residential location patterns. Can. Geogr. 2013, 58, 11-33. [CrossRef]

31. Moos, M. From gentrification to youthification? The increasing importance of young age in delineating high-density living. Urban Stud. 2016, 53, 2903-2920. [CrossRef]

32. Andersson, E.K.; Abramsson, M.; Malmberg, B. Patterns of changing residential preferences during late adulthood. Ageing Soc. 2018, 39, 1752-1781. [CrossRef]

33. Aradhya, S.; Hedefalk, F.; Helgertz, J.; Scott, K. Region of Origin: Settlement Decisions of Turkish and Iranian Immigrants in Sweden, 1968-2001. Popul. Space Place 2016, 23, e2031. [CrossRef]

34. Lawton, P.; Murphy, E.; Redmond, D. Residential preferences of the 'creative class'? Cities 2013, 31, 47-56. [CrossRef]

35. Terama, E.; Clarke, E.; Rounsevell, M.D.A.; Fronzek, S.; Carter, T.R. Modelling population structure in the context of urban land use change in Europe. Reg. Environ. Chang. 2017, 19, 667-677. [CrossRef]

36. Salvati, L. 'Rural' sprawl, Mykonian style: A scaling paradox. Int. J. Sustain. Dev. World Ecol. 2013, 20, 109-115. [CrossRef]

37. Kroll, F; Kabisch, N. The Relation of Diverging Urban Growth Processes and Demographic Change along an Urban-Rural Gradient. Popul. Space Place 2011, 18, 260-276. [CrossRef] 
38. Johnson, K.M.; Voss, P.R.; Hammer, R.B.; Fuguitt, G.V.; McNiven, S. Temporal and spatial variation in age-specific net migration in the United States. Demography 2005, 42, 791-812. [CrossRef]

39. Blangiardo, G.C.; Rimoldi, S.M.L. The potential demography: A tool for evaluating differences among countries in the European Union. Genus 2013, 68, 63-81.

40. Van Bavel, J.; Reher, D.S. The Baby Boom and Its Causes: What We Know and What We Need to Know. Popul. Dev. Rev. 2013, 39, 257-288. [CrossRef]

41. Taulbut, M.; Robinson, M. The Chance to Work in Britain: Matching Unemployed People to Vacancies in Good Times and Bad. Reg. Stud. 2014, 49,1-17. [CrossRef]

42. Sayas, J.P. Urban sprawl in the periurban coastal zones of Athens. Greek Rev. Soc. Res. 2016, 121, 71-104. [CrossRef]

43. Morelli, V.G.; Rontos, K.; Salvati, L. Between suburbanisation and re-urbanisation: Revisiting the urban life cycle in a Mediterranean compact city. Urban Res. Pract. 2014, 7, 74-88. [CrossRef]

44. Rontos, K.; Grigoriadis, E.; Sateriano, A.; Syrmali, M.; Vavouras, I.; Salvati, L. Lost in protest, found in segregation: Divided cities in the light of the 2015 "Oki" referendum in Greece. City Cult. Soc. 2016, 7, 139-148. [CrossRef]

45. Domingo, A.; Gil-Alonso, F. Immigration and changing labour force structure in the Southern European Union. Population 2007, 62, 709-727. [CrossRef]

46. Champion, A.G. A Changing Demographic Regime and Evolving Polycentric Urban Regions: Consequences for the Size, Composition and Distribution of City Populations. Urban Stud. 2001, 3, 657-677. [CrossRef]

47. Carrasco, J.B.; Gay, A.L. Concentración, segregación y movilidad residencial de los extranjeros en Barcelona. Documents d'Anàlisi Geogràfica 2011, 57, 381-412. [CrossRef]

48. Bayona, J.; Gil-Alonso, F.; Pujadas, I. Dinàmica residencial de la població estrangera en les principals' regions metropolitanes d'Espanya. Revista Catalana de Sociologia 2011, 27, 15-32.

49. Buzar, S.; Ogden, P.; Hall, R.; Haase, A.; Kabisch, S.; Steinfiihrer, A.; Bouzarovski, S. Splintering Urban Populations: Emergent Landscapes of Reurbanisation in Four European Cities. Urban Stud. 2007, 44, 651-677. [CrossRef]

50. Gil Alonso, F.; Carrasco, J.B.; Rúbies, I.P.; Pujadas-i-Rúbies, I. From boom to crash: Spanish urban areas in a decade of change (2001-2011). Eur. Urban Reg. Stud. 2013, 23, 198-216. [CrossRef]

51. Gil Alonso, F.; Carrasco, J.B.; Villanueva, C.L.; Rúbies, I.P. Diferencias geográficas de la fecundidad en España: Una perspectiva provincial. Papeles de Geografía 2017, 63, 21-38. [CrossRef]

52. Carruthers, J.I. Growth at the fringe: The influence of political fragmentation in United States metropolitan areas. Pap. Reg. Sci. 2003, 82, 475-499. [CrossRef]

53. Triantakonstantis, D.; Stathakis, D. Examining urban sprawl in Europe using spatial metrics. Geocarto Int. 2015, 30, 1092-1112. [CrossRef]

54. Couch, C.; Karecha, J. Controlling urban sprawl: Some experiences from Liverpool. Cities 2006, 23, 353-363. [CrossRef]

55. Wu, J. Environmental amenities, urban sprawl, and community characteristics. J. Environ. Econ. Manag. 2006, 52, 527-547. [CrossRef]

56. Christiansen, P.; Loftsgarden, T. Drivers behind urban sprawl in Europe. TØI Rep. 2011, 1136, 2011.

57. Andersen, H.S. Explanations for long-distance counter-urban migration into fringe areas in Denmark. Popul. Space Place 2009, 17, 627-641. [CrossRef]

58. Lin, B.B.; Gaston, K.; Fuller, R.; Wu, D.; Bush, R.; Shanahan, D. How green is your garden? Urban form and socio-demographic factors influence yard vegetation, visitation, and ecosystem service benefits. Landsc. Urban Plan. 2017, 157, 239-246. [CrossRef]

59. Kulu, H.; Boyle, P.; Andersson, G. High Suburban Fertility: Evidence from Four Northern European Countries. Demogr. Res. 2009, 21, 915-944. [CrossRef]

60. Colantoni, A.; Grigoriadis, E.; Sateriano, A.; Venanzoni, G.; Salvati, L. Cities as selective land predators? A lesson on urban growth, deregulated planning and sprawl containment. Sci. Total Environ. 2016, 545, 329-339. [CrossRef]

61. Hennig, E.I.; Schwick, C.; Soukup, T.; Orlitová, E.; Kienast, F.; Jaeger, J.A. Multi-scale analysis of urban sprawl in Europe: Towards a European de-sprawling strategy. Land Use Policy 2015, 49, 483-498. [CrossRef]

62. Hof, A.; Blàzquez-Salom, M. The Linkages between Real Estate Tourism and Urban Sprawl in Majorca (Balearic Islands, Spain). Land 2013, 2, 252-277. [CrossRef] 
63. Orenstein, D.E.; Hamburg, S.P. Population and pavement: Population growth and land development in Israel. Popul. Environ. 2010, 31, 223-254. [CrossRef]

64. Muñoz, F. Lock living: Urban sprawl in Mediterranean cities. Cities 2003, 20, 381-385. [CrossRef]

65. Serra, P.; Vera, A.; Tulla, A.F.; Salvati, L. Beyond urban-rural dichotomy: Exploring socioeconomic and land-use processes of change in Spain (1991-2011). Appl. Geogr. 2014, 55, 71-81. [CrossRef]

66. Cuadrado-Ciuraneta, S.; Durà-Guimerà, A.; Salvati, L. Not only tourism: Unravelling suburbanization, second-home expansion and "rural" sprawl in Catalonia, Spain. Urban Geogr. 2016, 38, 66-89. [CrossRef]

67. Sauri, D. Lights and Shadows of Urban Water Demand Management: The Case of the Metropolitan Region of Barcelona. Eur. Plan. Stud. 2003, 11, 229-243. [CrossRef]

68. Garcia-López, M.À.; Muñiz, I. Employment Decentralisation: Polycentricity or Scatteration? The Case of Barcelona. Urban Stud. 2010, 47, 3035-3056. [CrossRef]

69. Vidal, M.; Domene, E.; Sauri, D. Changing geographies of water-related consumption: Residential swimming pools in suburban Barcelona. Area 2010, 43, 67-75. [CrossRef]

70. Munafo, M.; Salvati, L.; Zitti, M. Estimating soil sealing rate at national level-Italy as a case study. Ecol. Indic. 2013, 26, 137-140. [CrossRef]

71. Bayona, I.C.J.; López-I-Villanueva, C.; Pujadas, I.R.I. Households within the residential mobility process: The case of the Barcelona metropolitan region. Archivio Studi Urbani e Regionali 2014, 28, 57-84. [CrossRef]

72. Garcia, X.; Palom, A.R.; Llausàs, A.; Sauri, D. Socio-demographic profiles in suburban developments: Implications for water-related attitudes and behaviors along the Mediterranean coast. Appl. Geogr. 2013, 41, 46-54. [CrossRef]

73. Durà-Guimerà, A. Desconcentración residencial y nueva fragmentación socioespacial en la región de Barcelona. Annales de geografía de la Universidad Complutense 1997, 17, 113-129.

74. Durà-Guimerà, A. Population deconcentration and social restructuring in Barcelona, a European Mediterranean city. Cities 2003, 20, 387-394. [CrossRef]

75. European Environment Agency. Urban Sprawl in Europe: The Ignored Challenge. Report Number 10/2006. Copenhagen: EEA. Available online: http://www.eea.europa.eu/publications/eea_report_2006_10 (accessed on 18 May 2020).

76. García-Palomares, J.C. Urban sprawl and travel to work: The case of the metropolitan area of Madrid. J. Transp. Geogr. 2010, 18, 197-213. [CrossRef]

77. Stead, D. Relationships between Land Use, Socioeconomic Factors, and Travel Patterns in Britain. Environ. Plan. B Plan. Des. 2001, 28, 499-528. [CrossRef]

78. Gutiérrez, J.; García-Palomares, J.C. New spatial patterns of mobility within the metropolitan area of Madrid: Towards more complex and dispersed flow networks. J. Transp. Geogr. 2007, 15, 18-30. [CrossRef]

79. Zlender, V.; Thompson, C.W. Accessibility and use of peri-urban green space for inner-city dwellers: A comparative study. Landsc. Urban Plan. 2017, 165, 193-205. [CrossRef]

80. Cervero, R. Built environments and mode choice: Toward a normative framework. Transp. Res. Part D Transp. Environ. 2002, 7, 265-284. [CrossRef]

81. Christie, N.; Steinbach, R.; Green, J.; Mullan, M.P.; Prior, L. Pathways linking car transport for young adults and the public health in Northern Ireland: A qualitative study to inform the evaluation of graduated driver licensing. BMC Public Health 2017, 17, 551. [CrossRef]

82. Tucker-Raymond, E.; Rosario, M.L. Imagining identities: Young people constructing discourses of race, ethnicity, and community in a contentious context of rapid urban development. Urban Educ. 2017, 52, 32-60. [CrossRef]

83. Green, S.; McCarthy, L. Is sharing the solution? Exploring the opportunities and challenges of privately rented shared accommodation for single people in housing need. People Place Policy Online 2015, 9, 159-176. [CrossRef]

84. Salmerón, L.; Macedo-Rouet, M.; Rouet, J.-F. Multiple viewpoints increase students' attention to source features in social question and answer forum messages. J. Assoc. Inf. Sci. Technol. 2015, 67, 2404-2419. [CrossRef]

85. Bricocoli, M.; Sabatinelli, S. House sharing amongst young adults in the context of Mediterranean welfare: The case of Milan. Int. J. Hous. Policy 2016, 16, 184-200. [CrossRef]

86. Steinführer, A.; Haase, A. Flexible-inflexible: Socio-demographic, spatial and temporal dimensions of flat sharing in Leipzig (Germany). Geojournal 2009, 74, 567-587. [CrossRef] 
87. Salvati, L.; Carlucci, M. A composite index of sustainable development at the local scale: Italy as a case study. Ecol. Indic. 2014, 43, 162-171. [CrossRef]

88. Salvati, L. Towards a Polycentric Region? The Socio-economic Trajectory of Rome, an 'Eternally Mediterranean' City. Tijdschrift voor Economische en Sociale Geografie 2013, 105, 268-284. [CrossRef]

89. Van Diepen, A.M.L.; Musterd, S. Lifestyles and the city: Connecting daily life to urbanity. J. Hous. Environ. 2009, 24, 331-345. [CrossRef]

90. Rose, D.; Villeneuve, P. Life stages, living arrangements and lifestyles: A century of change. In Canadian Cities in Transition: Local Through Global Perspectives; Bunting, T.E., Filion, P., Eds.; Oxford University Press: Don Mills, ON, Canada, 2006; pp. 138-153.

91. Hagestad, G.; Uhlenberg, O. Should we be concerned about age segregation? Some theoretical and empirical explorations. Res. Aging 2006, 28, 638-653. [CrossRef]

92. Vanderbeck, R.M. Intergenerational Geographies: Age Relations, Segregation and Re-engagements. Geogr. Compass 2007, 1, 200-221. [CrossRef]

93. Vogelsang, E.; Raymo, J.M. Local-area age structure and population composition: Implications for elderly health in Japan. J. Aging Health 2013, 26, 155-177. [CrossRef] [PubMed]

94. Kucukmehmetoglu, M.; Geymen, A. Urban sprawl factors in the surface water resource basins of Istanbul. Land Use Policy 2009, 26, 569-579. [CrossRef]

95. Zitti, M.; Ferrara, C.; Perini, L.; Carlucci, M.; Salvati, L. Long-Term Urban Growth and Land Use Efficiency in Southern Europe: Implications for Sustainable Land Management. Sustainablity 2015, 7, 3359-3385. [CrossRef]

96. Muñoz, R.D. International retirees at the polls: Spanish local elections 2015. RIPS: Revista de Investigaciones Políticas y Sociológicas 2018, 17, 27-54.

97. Zasada, I.; Alves, S.; Müller, F.C.; Piorr, A.; Berges, R.; Bell, S. International retirement migration in the Alicante region, Spain: Process, spatial pattern and environmental impacts. J. Environ. Plan. Manag. 2010, 53, 125-141. [CrossRef]

98. King, R.; Vullnetari, J. Orphan pensioners and migrating grandparents: The impact of mass migration on older people in rural Albania. Ageing Soc. 2006, 26, 783-816. [CrossRef]

99. Williams, A.M.; King, R.; Warnes, T. A place in the sun: International retirement migration from northern to southern Europe. Eur. Urban Reg. Stud. 1997, 4, 115-134. [CrossRef]

100. Castellano, J.M.P.; Mujica, J.D. Working and retiring in sunny Spain: Lifestyle migration further explored. Hung. Geogr. Bull. 2017, 65, 407-420. [CrossRef]

101. Alphan, H. Land use change and urbanisation of Adana, Turkey. Land Degrad. D-ev. 2003, 14, 575-586. [CrossRef]

102. Polyzos, S.; Christopoulou, O.; Minetos, D.; Filho, W.L. An overview of urban-rural land use interactions in Greece. Int. J. Agric. Resour. Gov. Ecol. 2008, 7, 276-296. [CrossRef]

103. Williams, A.M.; Hall, C.M. Tourism and migration: New relationships between production and consumption. Tour. Geogr. 2000, 2, 5-27. [CrossRef]

104. Gustafson, P. Your home in Spain: Residential strategies in international retirement migration. In Lifestyle Migrations: Expectations, Aspirations and Experiences; Benson, M., O’Reilly, K., Eds.; Ashgate: Farnham, UK, 2009.

105. Rodriguez, V.; Fernandez-Mayoralas, G.; Rojo-Perez, F. International Retirement Migration: Retired Europeans Living on the Costa Del Sol, Spain. Popul. Rev. 2004, 43, 1-36. [CrossRef]

106. Gallent, N.; Tewdwr-Jones, M. Rural Second Homes in Europe: Examining Housing Supply and Planning Control; Routledge: London, UK, 2018.

107. Rosso, A.L.; Auchincloss, A.H.; Michael, Y.L. The Urban Built Environment and Mobility in Older Adults: A Comprehensive Review. J. Aging Res. 2011, 2011, 1-10. [CrossRef] [PubMed]

108. Kazmierczak, A. The contribution of local parks to neighbourhood social ties. Landsc. Urban Plan. 2013, 109, 31-44. [CrossRef]

109. Williams, A.; King, R.; Warnes, A.; Patterson, G. Tourism and international retirement migration: New forms of an old relationship in southern Europe. Tour. Geogr. 2000, 2, 28-49. [CrossRef]

110. Grijalva, D.P.; Redrobán, V. Retirement here or there? Ageing-migrants' transnational social protection. In Boletín OEG de Investigación; European Observatory on Gerontomigration: Málaga, Spain, 2017; No. 14. 
111. King, R.; Warnes, T.; Allan, W. Sunset Lives: British Retirement Migration to the Mediterranean; Berg: Oxford, UK, 2000.

112. Oliver, C. Peer-Led Care Practices and 'Community' Formation in British Retirement Migration. Nord. J. Migr. Res. 2017, 7, 172-180. [CrossRef]

113. O'Reilly, K. Intra-European Migration and the Mobility-Enclosure Dialectic. Sociology 2007, 41, $277-293$. [CrossRef]

114. Coldron, K.; Ackers, L. (Ab) Using European Citizenship? EU Retired Migrants and the Exercise of Healthcare Rights. Maastricht J. Eur. Comp. Law 2007, 14, 287-302. [CrossRef]

115. Hall, K.; Hardill, I. Retirement migration, the 'other' story: Caring for frail elderly British citizens in Spain. Ageing Soc. 2014, 36, 562-585. [CrossRef]

116. Hall, K. Retirement migration and health: Growing old in Spain. In Handbook Migration and Health; Edward Elgar Publishing Limited: Cheltenham, UK, 2017; p. 402.

117. Gustafson, P. Tourism and seasonal retirement migration. Ann. Tour. Res. 2002, 29, 899-918. [CrossRef]

118. Jones, C.A.; Kandel, W.; Parker, T. Population dynamics are changing the profile of rural areas. J. Rural. Ment. Health 2007, 31, 46-53. [CrossRef]

119. Monfort, J.G.; Hall, K.; Betty, C. Back to Brit: Retired British migrants returning from Spain. J. Ethn. Migr. Stud. 2015, 42, 797-815. [CrossRef]

120. Campos, R.A. Retirement Migration in Spain: Two Cases Studies in Catalonian and Mallorca. MOJ Gerontol. Geriatr. 2018, 3, 72. [CrossRef]

121. Halseth, G. Communities with communities: Changing residential areas at Culthus Lake, British Columbia. J. Rural Stud. 1993, 9, 175-187. [CrossRef]

122. Gavanas, A.; Calzada, I. Multiplex Migration and Aspects of Precarization: Swedish Retirement Migrants to Spain and their Service Providers. Crit. Sociol. 2016, 42, 1003-1016. [CrossRef]

123. Warnes, A.M.; Williams, A. Older Migrants in Europe: A New Focus for Migration Studies. J. Ethn. Migr. Stud. 2006, 32, 1257-1281. [CrossRef]

124. Benson, M. A Desire for Difference: British Lifestyle Migration to Southwest France. In Lifestyle Migration: Expectations, Aspirations and Experiences; Benson, M., O’Reilly, K., Eds.; Ashgate: Farnham, UK, 2009; pp. 1-13.

125. Zontini, E. Growing old in a transnational social field: Belonging, mobility and identity among Italian migrants. Ethn. Racial Stud. 2014, 38, 326-341. [CrossRef]

126. Müller, D. Reinventing the Countryside: German Second-home Owners in Southern Sweden. Curr. Issues Tour. 2002, 5, 426-446. [CrossRef]

127. Hannonen, O. Second homeowners as tourism trend-setters: A case of residential tourists in Gran Canaria. J. Spat. Organ. Dyn. 2018, 6, 345-359.

128. Casado-Díaz, M.A.; Kaiser, C.; Warnes, A.M.; Casado-Daz, M.A. Northern European retired residents in nine southern European areas: Characteristics, motivations and adjustment. Ageing Soc. 2004, 24, 353-381. [CrossRef]

129. Breuer, T. Retirement Migration or rather Second-Home Tourism? German Senior Citizens on the Canary Islands. Die Erde 2005, 136, 313-333.

130. Bondi, L. Gender, Class, and Gentrification: Enriching the Debate. Environ. Plan. D Soc. Space 1999, 17, 261-282. [CrossRef]

131. Zeitler, E.; Buys, L. Mobility and out-of-home activities of older people living in suburban environments: 'Because I'm a driver, I don't have a problem'. Ageing Soc. 2014, 35, 785-808. [CrossRef]

132. Burholt, V. Transnationalism, economic transfers and families' ties: Intercontinental contacts of older Gujaratis, Punjabis and Sylhetis in Birmingham with families abroad. Ethn. Racial Stud. 2004, 27, 800-829. [CrossRef]

133. Ramji, H. British Indians 'Returning Home': An Exploration of Transnational Belongings. Sociology 2006, 40, 645-662. [CrossRef]

134. White, P. Migrant Populations Approaching Old Age: Prospects in Europe. J. Ethn. Migr. Stud. 2006, 32, 1283-1300. [CrossRef]

135. Andrew, M.K.; Mitnitski, A.B.; Rockwood, K. Social Vulnerability, Frailty and Mortality in Elderly People. PLoS ONE 2008, 3, e2232. [CrossRef]

136. Deller, S.C. Economic Impact of Retirement Migration. Econ. Dev. Q. 1995, 9, 25-38. [CrossRef] 
137. Bennett, D.G. Retirement Migration and Economic Development in High-Amenity, Nonmetropolitan Areas. J. Appl. Gerontol. 1993, 12, 466-481. [CrossRef]

138. De Rosa, S.; Salvati, L. Beyond a 'side street story'? Naples from spontaneous centrality to entropic polycentricism, towards a 'crisis city'. Cities 2016, 51, 74-83. [CrossRef]

139. Di Feliciantonio, C.; Salvati, L. 'Southern' Alternatives of Urban Diffusion: Investigating Settlement Characteristics and Socio-Economic Patterns in Three Mediterranean Regions. Tijdschrift voor Economische en Sociale Geografie 2014, 106, 453-470. [CrossRef]

140. Hardill, I.; Spradbery, A.; Arnold-Boakes, J.; Marrugat, M.L. Severe health and social care issues among British migrants' whore tire to Spain. Ageing Soc. 2005, 25, 769-783. [CrossRef]

141. Carlucci, M.; Grigoriadis, E.; Rontos, K.; Salvati, L. Revisiting a Hegemonic Concept: Long-term 'Mediterranean Urbanization' in Between City Re-polarization and Metropolitan Decline. Appl. Spat. Anal. Policy 2016, 10, 347-362. [CrossRef]

142. Domene, E.; Sauri, D. Urbanisation and Water Consumption: Influencing Factors in the Metropolitan Region of Barcelona. Urban Stud. 2006, 43, 1605-1623. [CrossRef]

143. Morote, Á.F.; Sauri, D.; Hernández, M. Residential Tourism, Swimming Pools, and Water Demand in the Western Mediterranean. Prof. Geogr. 2016, 69, 1-11. [CrossRef]

144. Bayona-Carrasco, J.; Carrasco, J.B.; Gil-Alonso, F. Suburbanisation and international immigration: The case of the Barcelona Metropolitan Region (1998-2009). Tijdschrift voor Economische en Sociale Geografie 2011, 103, 312-329. [CrossRef]

145. González-Pérez, J.M. The Real Estate and Economic Crisis: An Opportunity for Urban Return and Rehabilitation Policies in Spain. Sustainability 2010, 2, 1571-1601. [CrossRef]

146. Bell, M. The Spatial Distribution of Second Homes: A Modified Gravity Model. J. Leis. Res. 1977, 9, $225-233$. [CrossRef]

147. Nijkamp, P.; Vanwissen, L.; Rima, A. A household life-cycle model for residential relocation behavior. Socio-Econ. Plan. Sci. 1993, 27, 35-53. [CrossRef]

148. Shelley, M.; Koven, S.G. Interstate Migration: A Test of Competing Interpretations. Policy Stud. J. 1993, 21, 243-261. [CrossRef]

149. Davis, J.S.; Nelson, A.C.; Dueker, K.J. The New' Burbs The Exurbs and Their Implications for Planning Policy. J. Am. Plan. Assoc. 1994, 60, 45-59. [CrossRef]

150. Riebsame, W.E.; Gosnell, H.; Theobald, D.M. Land Use and Landscape Change in the Colorado Mountains I: Theory, Scale, and Pattern. Mt. Res. Dev. 1996, 16, 395-405. [CrossRef]

151. Gober, P.; McHugh, K.E.; Leclerc, D. Job-Rich but Housing-Poor: The Dilemma of a Western Amenity Town. Prof. Geogr. 1993, 45, 12-20. [CrossRef]

152. Halseth, G.; Rosenberg, M. Cottagers in an Urban Field. Prof. Geogr. 1995, 47, 148-159. [CrossRef]

153. Gustafson, P. Transnationalism in retirement migration: The case of North European retirees in Spain. Ethn. Racial Stud. 2008, 31, 451-475. [CrossRef]

154. Zambon, I.; Serra, P.; Sauri, D.; Carlucci, M.; Salvati, L. Beyond the 'Mediterranean city': Socioeconomic disparities and urban sprawl in three Southern European cities. Geogr. Ann. Ser. B Hum. Geogr. 2017, 99, 319-337. [CrossRef]

155. Ward, N.; Lowe, P.; Seymour, S.; Clark, J. Rural Restructuring and the Regulation of Farm Pollution. Environ. Plan. A: Econ. Space 1995, 27, 1193-1211. [CrossRef]

156. Ursache, M. Tourism-Significant Driver Shaping a Destinations Heritage. Procedia Soc. Behav. Sci. 2015, 188, 130-137. [CrossRef]

157. Flynn, A.; Marsden, T.K. Rural change, regulation and sustainability. Environ. Plan. A 1995, 27, 1180-1192. [CrossRef]

158. Zambon, I.; Benedetti, A.; Ferrara, C.; Salvati, L. Soil Matters? A Multivariate Analysis of Socioeconomic Constraints to Urban Expansion in Mediterranean Europe. Ecol. Econ. 2018, 146, 173-183. [CrossRef]

159. Simou, E.; Koutsogeorgou, E. Effects of the economic crisis on health and healthcare in Greece in the literature from 2009 to 2013: A systematic review. Health Policy 2014, 115, 111-119. [CrossRef] [PubMed]

160. Pujadas, I.; Bayona, J.; Gil-Alonso, F.; López-Villanueva, C. Diferenciación espacial en los comportamientos demográficos: El caso de la fecundidad en la Región Metropolitana de Barcelona (1986-2010). In La población en Clave Territorial. Procesos, Estructuras y Perspectivas de Anàlisis; Reques, P., de Cos, O., Eds.; Universidad de Cantabria: Santander, Spain, 2012; pp. 145-154. 
161. Rivera, E.P.; Moya, J.M.R. Diferencias socioespaciales en la fecundidad madrileña en el cambio de siglo. Estudios Geográficos 2003, 64, 455-486. [CrossRef]

162. Rontos, K.; Salvati, L. Is the Ratio of Present to Resident Population a Proxy for Urban Diffusion? A Case Study. Int. J. Ecol. Econ. Stat. 2014, 32, 75-82.

163. Ren, X. City power and urban fiscal crises: The USA, China, and India. Int. J. Urban Sci. 2015, 19, 73-81. [CrossRef]

164. Kinsella, K. Urban and rural dimensions of global population aging: An overview. J. Rural. Health 2001, 17, 314-322. [CrossRef] [PubMed]

165. Lord, S.; Joerin, F.; Thériault, M. Daily mobility of aging and elderly suburbanites: Trips, aspirations and meanings of mobility. Can. Geogr. 2009, 53, 3.

166. Lowe, P.; Murdoch, J.; Marsden, T.; Munton, R.; Flynn, A. Regulating the new rural spaces: The uneven development of land. J. Rural Stud. 1993, 9, 205-222. [CrossRef]

167. Lucy, W.H.; Phillips, D.L. Suburban decline: The next urban crisis. Issues Sci. Technol. 2000, 17, $55-62$.

168. Marek, K.D.; Rantz, M.J. Aging in Place: A New Model for Long-Term Care. Nurs. Adm. Q. 2000, $24,1-11$. [CrossRef]

169. Charlton, J.L.; Oxley, J.; Fildes, B.; Oxley, P.; Newstead, S.; Koppel, S.; O’Hare, M. Characteristics of older drivers who adopt self-regulatory driving behaviours. Transp. Res. Part F Traffic Psychol. Behav. 2006, 9, 363-373. [CrossRef]

170. Phillips, M. Rural gentrifcation and the processes of class colonization. J. Rural Stud. 1993, 9, $123-140$. [CrossRef]

(C) 2020 by the authors. Licensee MDPI, Basel, Switzerland. This article is an open access article distributed under the terms and conditions of the Creative Commons Attribution (CC BY) license (http://creativecommons.org/licenses/by/4.0/). 